\title{
Effect of Bicarbonate Stress on Carbonic Anhydrase Gene Expressions from Orychophragmus violaceus and Brassica juncea seedlings
}

\author{
Hongtao Hang ${ }^{1,2}$, Yanyou $\mathrm{Wu}^{3 *}$
}

${ }^{1}$ School of Karst Science, Guizhou Normal University, Guiyang, Guizhou, P.R. China ${ }^{2}$ State Engineering Technology Institute for Karst Desertification Control, Guiyang, Guizhou, P.R. China

${ }^{3}$ Research Centre for Environmental Bio-Science and Technology, State Key Laboratory of Environmental Geochemistry, Institute of Geochemistry, Chinese Academy of Sciences,

Guiyang, Guizhou, P.R. China

Received: 23 December 2017

Accepted: 20 March 2018

\begin{abstract}
Three $\beta$-type genes coding for carbonic anhydrase and CA activities from Orychophragmus violaceus L. and Brassica juncea L. leaves in response to $\mathrm{NaHCO}_{3}$-induced bicarbonate stress were examined. Three full-length cDNA CDS sequences were designated as OvCA1, OvCA3, and OvCA4 in Orychophragmus violaceus, and as BjCA1, BjCA3, and BjCA4 in Brassica juncea; these genes encoding $\beta$-CAs were identified and characterized. In particular, $O v C A 1$ and $B j C A 1$ encode two putative chloroplast isoforms. $O v C A 3$ and $B j C A 3$ encode two putative cytosolic isoforms. $O v C A 4$ and $B j C A 4$ encode two putative plasma membrane isoforms. Quantitative real-time RT-PCR analysis revealed that OvCA1 and OvCA4 expressions in Orychophragmus violaceus, BjCA1, and BjCA4 expressions in Brassica juncea changed synchronously with CA activities as bicarbonate stress was intensified. Bicarbonate stress synchronously stimulated $O v C A 1$ and $O v C A 4$ expressions along with CA activities in Orychophragmus violaceus at slight stress level; but it decreased CA activity, BjCAl and BjCA4 expressions, and stimulated BjCA3 expression in Brassica juncea. Orychoophragmus violaceus could better adapt to slight bicarbonate stress than Brassica juncea due to the former exhibiting higher $O v C A 3$ expression levels and CA activities than the latter. The responses of $C A 1$ and CA4 in Orychophragmus violaceus and $C A 3$ in Brassica juncea to bicarbonate stress partly regulate $\mathrm{HCO}_{3}^{-}$to water and $\mathrm{CO}_{2}$ supplied to plants. Diverse CA gene expressions can partially account for different adaptation strategies of the two plant species subjected to different bicarbonate stress levels.
\end{abstract}

Keywords: bicarbonate, Orychophragmus violaceus, Brassica juncea, carbonic anhydrase, gene expression

*e-mail: wuyanyou@mail.gyig.ac.cn 


\section{Introduction}

Bicarbonate stress is considered the major abiotic stress that cause adverse effects on plant growth and crop productivity globally $[1,2]$, especially in karst regions, where the major anions from the soil solution of calcareous soils are $\mathrm{HCO}_{3}^{-}$and $\mathrm{CO}_{3}{ }^{2-}$, which are the severe harmful factors for the plants [3]. Sodium bicarbonate, which brings to high levels of $\mathrm{pH}, \mathrm{Na}^{+}$, $\mathrm{HCO}_{3}^{-}$, and $\mathrm{CO}_{3}^{2-}$, lead to distraction of intracellular $\mathrm{pH}$, hypertonic stress, and ultimately affect plant growth and development $[4,5]$. Exposed to bicarbonate stress, the plants have to resist adverse bicarbonate stress because they do not avoid it, thus plants have to develop a series of complex systems of signal transduction to respond and adapt to bicarbonate stress [6,7]. Such systems are correlated with reprogramming of downstream regulation and significant environmental stressinducible genes expression $[8,9]$. Recently, a number of genes have been discovered and demonstrated the correlation between bicarbonate stress and expression of these genes. Consequently, the production of osmolytes and proteins are induced to regulate the hyperosmotic of cytoplasm in plant tissues [10, 11]. However, some studies have suggested that adding a certain amount of bicarbonate to culture medium can improve the growth of the plants [12-14]. But excessive levels of bicarbonate often affect normal growth and development of some plants [15]. Furthermore, a great many studies have been devoted to exploring and selecting the ideal bicarbonateresistant plants based on the wide adaptability of plants [16].

Orychophragmus violaceus (L.) and Brassica juncea (L.), which are both cruciferous plant species, and some studies indicated that Orychophragmus violaceus grew better in limestone soil in the karst region than Brassica juncea in correlation with higher photosynthetic activity and bicarbonate-use capacity of Orychophragmus violaceus [17, 18], demonstrating that Orychophragmus violaceus has developed physiological and molecular mechanisms to adapt to karst adversity. Therefore, Orychophragmus violaceus is an ideal plant for determining the physiological and molecular mechanisms of plant bicarbonate stress tolerance. However, Brassica juncea is widely grown in southwest china due to its tolerance of bicarbonate stress [19]; it was used as the control plant and compared with Orychophragmus violaceus in identifying the differences in response to bicarbonate stress.

Carbonic anhydrase (CA, EC 4.2.1.1) is a zinccontaining metalloenzyme in living organisms, with the key function as catalysing the reversible interconversion of $\mathrm{HCO}_{3}{ }^{-}$and $\mathrm{CO}_{2}$ [20]. A number of studies have demonstrated that the $\mathrm{CA}$ family contribute to the regulation of various biochemical processes. In higher plants, CA can provide ample inorganic carbon for carboxylases, such as ribulose-bisphospate and phosphoenolpyruvate carboxylase, for photosynthetic assimilation [21-23]. However, CA activities and gene expression levels in response to different bicarbonate stresses varied in terms of plant species and the extent of stress.

A great many studies have found four types of CAs (i.e., $\alpha-, \beta-, \gamma-$ and $\delta$ ), which are crucial to plant cells and are involved in various physiological and biochemical processes [20]. Recently, many CA family genes have been investigated; in particular, the $\beta$-CA class predominate most in all known CAs in higher plants [24]. The known model plant Arabidopsis thaliana and the roles and locations of CA have been reported in recent years $[25,26]$. All At $\beta C A s$ (AtBCA1-6) and three At $\alpha C A s$ of Arabidopsis thaliana have been reported to be expressed in all green tissues. Six At $B C A s$ are located in the chloroplast ( $A t \beta C A 1$ and $A t \beta C A 5)$, mitochondria $(A t \beta C A 6)$, and plasma membranes (At $\beta C A 4)$, and within the cytoplasm (AtBCA2 and $A t \beta C A 3)$, respectively. Some studies have reported that the $\mathrm{CA}$ gene expressions in response to different atmospheric $\mathrm{CO}_{2}$ supply changes to regulate the inorganic carbon utilization to maintain carbon metabolic process [21-26]. However, the functions of $\mathrm{CAs}$ in the $\mathrm{C}_{3}$ plant photosynthesis are still unclear.

Arabidopsis thaliana, Orychophragmus violaceus, and Brassica juncea are all cruciferous $\mathrm{C}_{3}$ plants. Numerous studies have reported the functions and localization of CAs in A. thaliana [25]. However, little information is known regarding the functions and localizations of CAs in the other two plant species. This study revealed three distinct cDNA sequences which, when encoding CA in O. violaceus and B. juncea, have been sequenced and aligned to the high homologous beta $\mathrm{CA}$ sequences in $A$. thaliana. These sequences include CA1 (locus At3g01500) encoding chloroplast CA, CA3 (locus At1g23730) encoding cytoplasmic CA, and $C A 4$ (locus Atlg70410) encoding plasma membrane $\mathrm{CA}$ in A. thaliana. Furthermore, the experimental results showed that the CA enzyme is inducible and responds to increasing levels of bicarbonate in water culture conditions. Three distinct CA gene expressions are investigated. The aim of the present study is to elucidate the differences of CA genes expression in response to $\mathrm{NaHCO}_{3}$-induced bicarbonate stress in $O$. violaceus and B. juncea.

\section{Material and Methods}

\section{Plant Materials and Bicarbonate-Stress Treatments}

Orychophragmus violaceus (L.) O. E. Schulz and Brassica juncea (L.) Czern.et Coss. cv. Zangyou No. 8 were used as the experimental materials, which were grown in the laboratory of the Institute of Geochemistry, Chinese Academy of Sciences, Guizhou Province, China $\left[26.35^{\circ} \mathrm{N}, 106.42^{\circ} \mathrm{E}\right]$. The experiment was performed from July 14 to September 21 . The seeds of two plant species were germinated in 12-hole trays 
containing perlites in a greenhouse under a 12-h light cycle $\left(400 \mu \mathrm{mol} \cdot \mathrm{m}^{-2} \cdot \mathrm{s}^{-1}\right.$, PPFD), a day/night temperature range of $25 / 18^{\circ} \mathbf{C}$, and a relative humidity range of $50-60 \%$. After germination, the seedlings with uniform sizes were selected and cultured with half-strength Hoagland nutrient solution [27]. After two months, the two cruciferous plant species were exposed to bicarbonate treatments by adding sodium bicarbonate to modified Hoagland nutrient solution. The modified Hoagland nutrient solution contained $6 \mathrm{mM} \mathrm{KNO}_{3}$, $4 \mathrm{mM} \mathrm{Ca}\left(\mathrm{NO}_{3}\right)_{2}, 2 \mathrm{mM} \mathrm{MgSO}, 0.25 \mathrm{mM} \mathrm{NH}_{4} \mathrm{H}_{2} \mathrm{PO}_{4}$, $0.75 \mathrm{mM} \mathrm{NH} \mathrm{NH}_{4}, 2 \mathrm{mM} \mathrm{Fe}(\mathrm{Na})$ EDTA, $2 \mu \mathrm{M} \mathrm{KCl}$, $50 \mu \mathrm{M} \mathrm{H}_{3} \mathrm{BO}_{3}, 4 \mu \mathrm{M} \mathrm{MnSO}_{4}, 4 \mu \mathrm{M} \mathrm{ZnSO}, 0.2 \mu \mathrm{M}$ $\mathrm{CuSO}_{4}$, and $0.2 \mu \mathrm{M}\left(\mathrm{NH}_{4}\right)_{6} \mathrm{M}_{\mathrm{O} 7} \mathrm{O}_{24}$ at $\mathrm{pH} 8.30 \pm 0.05$. The modified Hoagland nutrient solution included four concentrations of sodium bicarbonate (i.e., 0, 5, 10, and $15 \mathrm{mM} \mathrm{NaHCO}$ ). The modified Hoagland nutrient solution was changed daily to maintain a constant extent of each stress. Measurements were performed after $7 \mathrm{~d}$.

\section{Measurement of Carbonic Anhydrase Activities of Leaves in the Two Plant Species}

The third fully expanded leaf from the top of the two plant species was chosen for measuring carbonic anhydrase activity. About $0.1 \mathrm{~g}$ of leaves (fresh weight) were quickly frozen in liquid nitrogen and ground into power with a mill, then the sample was ground with $3 \mathrm{ml}$ extracted buffer $(0.01 \mathrm{M}$ barbitone sodium with $0.05 \mathrm{M}$ 2-mercaptoethanol, $\mathrm{pH}$ 8.30). The homogenate was centrifuged at $10,000 \times \mathrm{g}$ and $4^{\circ} \mathrm{C}$ for $10 \mathrm{~min}$ before being placed on ice for $20 \mathrm{~min}$. Then the supernatant was used to measure the activity of carbonic anhydrase using the method with modifications [28]. CA activity was measured at $0-2^{\circ} \mathrm{C}$ in a container consisting of $4.5 \mathrm{ml} 0.02 \mathrm{M}$ baritone buffer (5, 5-diethylbarbituric acid; $\mathrm{pH} 8.30$ ), $0.4 \mathrm{ml}$ sample, and $3 \mathrm{ml} \mathrm{CO}_{2}$-saturated $\mathrm{H}_{2} \mathrm{O}$. The carbonic anhydrase activity was defined as $\mathrm{WA}=\left(\mathrm{t}_{0} / \mathrm{t}\right)-1$, where $\mathrm{t}_{0}$ and $\mathrm{t}$ were the times $(\mathrm{s})$ taken from the enzyme-free buffer and the supernatant of the sample. At the same time, the protein content of leaves was determined by the Coomassie brilliant blue method [29].

\section{Identifying and Characterizing cDNA Coding for $\beta$-CAs}

Searches within public NCBI databases revealed the presence of three distinct nucleotide sequences in $O$. violaceus and B. juncea coding for $\beta$-CAs. The corresponding nucleotide sequences, which were aligned, and the complete nucleotide open reading frame (ORF) of the cDNA sequences were determined (NCBI, USA, ncbi.nlm.nih.gov) (Table 1). The deduced amino acid sequences suggested the presence of $O$. violaceus and $B$. juncea CA cDNAs, respectively. These distinct mRNA sequences of the two plant species were conducted for multiple alignments with ClustalX
Table 1. Basic information of the CA genes in O. violaceus and B. juncea.

\begin{tabular}{|c|c|c|c|c|}
\hline S. No. & Genes & $\begin{array}{c}\text { Full CDS } \\
\text { length (bp) }\end{array}$ & $\begin{array}{c}\text { Protein } \\
\text { length }\end{array}$ & $\begin{array}{c}\text { GenBank } \\
\text { accession No. }\end{array}$ \\
\hline 1 & OvCA1 & 996 & 331 & KM586043 \\
\hline 2 & OvCA3 & 777 & 258 & KM586044 \\
\hline 3 & OvCA4 & 777 & 258 & KM586045 \\
\hline 4 & BjCA1 & 1014 & 337 & KM586046 \\
\hline 5 & BjCA3 & 780 & 259 & KM586047 \\
\hline 6 & BjCA4 & 777 & 258 & KM586048 \\
\hline
\end{tabular}

version 1.8, and the results of evolutionary trees were run with the Neighbour-Joining method [30].

\section{RNA Extraction and Real-Time RT-PCR Analysis}

The same levels used as the experiment for measuring CA activities were harvested and ground in liquid nitrogen for gene expression analysis. They were harvested on the seventh day after the bicarbonate stress treatment. Extraction of total RNA was performed on $80 \mathrm{mg}$ of each plant material according to the method [31] described by the plant rna purification reagent (Invitrogen). To determine the gene expression accurately and eliminate first the contaminating genomic DNA during the purification of RNA, all the total RNA samples were treated and reverse-transcribed according to the instructions of the manufacturer using a Prime SCRIPT RT reagent kit with gDNA eraser (Perfect Real Time) (TaKaRa code: DRR047S). Furthermore, the concentration of each RNA treatment and material was determined by measuring the sample absorbance of RNA (A260/A280) using a spectrophotometer. Afterward, these samples were stored at $-80^{\circ} \mathrm{C}$ for determining the expression of genes encoding CA using real-time RT-PCR analysis.

The three distinct genes whose expressions were to be studied on the influence by bicarbonate were OvCA1 and BjCA1, coding for tow putative chloroplast isoforms $\mathrm{CA} ; \mathrm{O} C A 3$ and $B j C A 3$ coding for two putative cytoplasmic isoforms $\mathrm{CA}$; and $O v C A 4$ and $B j C A 4$ coding for two putative plasma membrane isoforms CA. The actin genes in $O$. violaceus and $B$. juncea were used as internal standard in the quantitative RT-PCR reaction, termed as Ovactin (GenBank accession No. KC979147) and Bjactin (GenBank accession No. KC979151), respectively. O. violaceus and $B$. juncea gene-specific primers were designed with Primer 5.0 software (Premier Biosoft International, USA) (Table 2).

Quantitative RT-PCRs were run in a 48-well Applied Biosystems one-step real-time PCR system using a SYBR green master mix (Applied Biosciences, USA), $1 \mu \mathrm{g}$ of the cDNA as template, and the gene-specific 
Table 2. Lists of primers used for Quantitative RT-PCR.

\begin{tabular}{|c|c|c|c|}
\hline S. No. & Genes & Forward primers $\left(5^{\prime} \rightarrow 3^{\prime}\right)$ & Reverse primers $\left(5^{\prime} \rightarrow 3^{\prime}\right)$ \\
\hline 1 & OvCA1 & CGGCGGAACTTAAGACAGGT & CTCCTTTGCCAGTCACCGTA \\
\hline 2 & OvCA3 & CTTCGACGATCAGTGCACCA & GTGAGCTCCTCTTATGGCGA \\
\hline 3 & OvCA4 & AGAAGGCAGATCTGGGGAAC & TTGATTCGTTCAACGGCGTC \\
\hline 4 & Ovactin & CGTTGCCCTGAGGTTCTCTT & TTGAACCACCACTGAGGACG \\
\hline 5 & BjCA1 & ATCCGTAACGAGCCCATTCT & GGCCTCTTGGTATGATTCGCT \\
\hline 6 & BjCA3 & TCCAAGCGACACATTCACAG & AAGAACAGGGTCAAGCAGGAA \\
\hline 7 & BjCA4 & GAACCGAGCACTGTCCTTCAA & ATTCCAGCAACTCTGACGCC \\
\hline 8 & Bjactin & GGAATGGTTAAGGCTGGTTTCG & GTTGTTGACGATGCCGTGTT \\
\hline
\end{tabular}

primers at a finial concentration of $0.5 \mu \mathrm{M}$. The PCR conditions were 40 cycles of $95^{\circ} \mathrm{C}$ for $15 \mathrm{~s}$ and $60^{\circ} \mathrm{C}$ for $1 \mathrm{~min}$. A modification of the comparative threshold cycle method was used for the relative quantification of gene expression. In the case of different bicarbonate stress treatments, relative transcript levels of the target gene $(\mathrm{X})$ were calculated as a ratio to the expressed actin gene transcripts (a), as $(1+\mathrm{E})^{-\Delta \mathrm{Ct}}$; where $\Delta \mathrm{Ct}$ was calculated as $\left(\mathrm{Ct}^{\mathrm{x}}-\mathrm{Ct}^{\mathrm{a}}\right)$, and $\mathrm{E}$ value, which represented the PCR efficiency for each amplification, was calculated with the linear regression method [32]. All these realtime RT-PCRs were examined on six biological repeats.

\section{The Log Relationship between Relative Gene} Expression and Relative CAActivity

In order to identify the differences of three distinct beta-type $\mathrm{CA}$ genes expression in $O$. violaceus and $B$. juncea, we examined log equation to describe the log relationship between relative gene expression (RGB) and

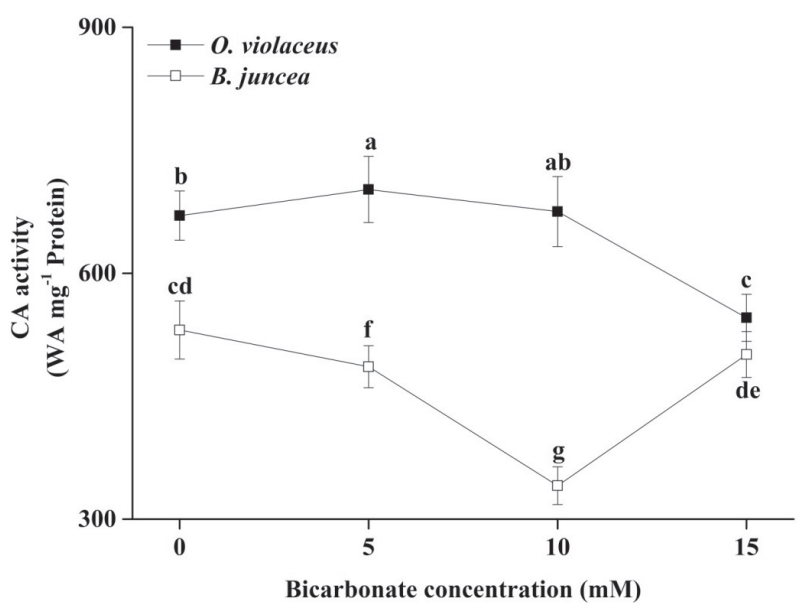

Fig. 1. CA activities of leaves in Orychophragmus violaceus and Brassica juncea seedlings subjected to bicarbonate treatment. Values show means $\pm \mathrm{SE}(n=6)$, which are presented using different letters showing significant differences in these characteristics at $P<0.05$ between group means, according to one-way ANOVA and $t$-test. relative CA activity (RCA). The RGB and RCA were calculated as: $\operatorname{RGB}(\mathrm{RCA})=\log \left(a_{t} / a_{0}\right)$, where $a_{t}$ is the value of relative gene expression or CA activity at each bicarbonate treatment, and $a_{0}$ is the value of relative gene expression or CA activity at the control $(0 \mathrm{mM}$ $\mathrm{NaHCO}_{3}$ ), respectively.

\section{Data Analysis}

The overall measurement data were subjected to ANOVA to determine significant differences (defined as $P<0.05$ ) between group means. Data were shown as mean \pm standard error (SE) using a factorial analysis of SPSS software (version 20.0). The mean results were compared by Duncan post hoc test at $5 \%$ significance level $(P<0.05)$. All the diagrams were constructed using Origin software (version 8.5).

\section{Results}

\section{CA Activities and Protein Content in O. violaceus and $B$. juncea Leaves}

The CA activities in leaves of the two cruciferous plant species under $\mathrm{NaHCO}_{3}$-induced bicarbonate stress were examined and described as WA $\mathrm{mg}^{-1}$ protein (Fig. 1). Obviously, CA activities did vary in terms of plant species and the extent of bicarbonate treatments. CA activities were higher in $O$. violaceus than in $B$. juncea among the bicarbonate treatments. The highest $\mathrm{CA}$ activity in $O$. violaceus was $5 \mathrm{mM}$ $\mathrm{NaHCO}_{3}$ and reached $106 \%$, and the lowest CA activity was $96 \%$ of the control at $15 \mathrm{mM} \mathrm{NaHCO}_{3}$, respectively. However, CA activities in $B$. juncea were significantly lower in $\mathrm{NaHCO}_{3}$-treatment than the control, but the CA activity at $15 \mathrm{mM} \mathrm{NaHCO}$, was higher than the control. Similarly, the protein content of seedlings in the two plant species under bicarbonate treatments were examined (Table 3). With the increasing concentration of bicarbonate treatments, the protein content changed synchronously with CA activities in the two plant species. 
Table 3. Protein contents of leaves in the in $O$. violaceus and B. juncea.

\begin{tabular}{|c|c|c|}
\hline $\begin{array}{c}\text { Bicarbonate } \\
\text { treatments }(\mathrm{mM})\end{array}$ & Plant species & $\begin{array}{c}\text { Protein content } \\
\left(\mathrm{mg} \mathrm{g}^{-1} \mathrm{FW}\right)\end{array}$ \\
\hline \multirow{2}{*}{0} & O. violaceus & $5.53 \pm 0.02$ \\
\cline { 2 - 3 } & B. juncea & $5.18 \pm 0.01$ \\
\hline \multirow{2}{*}{5} & O. violaceus & $5.68 \pm 0.05$ \\
\cline { 2 - 3 } & B. juncea & $4.89 \pm 0.02$ \\
\hline \multirow{2}{*}{10} & O. violaceus & $5.99 \pm 0.05$ \\
\cline { 2 - 3 } & B. juncea & $4.50 \pm 0.03$ \\
\hline \multirow{2}{*}{15} & O. violaceus & $5.40 \pm 0.04$ \\
\cline { 2 - 3 } & B. juncea & $4.80 \pm 0.01$ \\
\hline
\end{tabular}

\section{Identification and Characterization of cDNA Coding for CA}

The coding of three cDNAs for CA in the two plant species were obtained in our laboratory, and the three putative CA domain-containing protein sequences in the two cruciferous plant species were aligned, and the deduced amino acid sequences suggested the presence of cDNAs, which represented three full-length complete open reading frames (ORF) coding for $\mathrm{CA}$, respectively. The cDNAs of $O$. violaceus, namely $O v C A 1, O v C A 3$, and $O v C A 4$, and those of $B$. juncea, namely BjCAl, $B j C A 3$, and $B j C A 4$, were subsequently determined. To identify these CA gene families, we conducted a similarity search of sequences using the BLAST algorithm. The corresponding sequences were also aligned and characterized. Sequence alignments showed that these CA sequences are considerably similar to the $\beta C A$ gene families. Multiple sequence alignments of the CA gene products of the two plant species are shown in Fig. 2. The relationship is indicated by a high E value score. The three cDNA sequences of the two plants were compared with previously characterized $\beta$-CAs. Our results revealed that these sequences - OvCA1 and $B j C A 1$ - are highly similar to chloroplast isoforms CA ( $\beta$-CA1); OvCA3 and BjCA3 are highly similar to cytoplasmic isoforms $\mathrm{CA}(\beta-\mathrm{CA} 3)$; and $O v C A 4$ and $B j C A 4$ are highly similar to plasma membrane isoforms CA $(\beta-\mathrm{CA} 4)$.

\section{Relative Expression of the Three CAs in the Two Plant Species}

After the presence of the CA activities and three CA isoforms in the two cruciferous plants have been experimentally established and characterized in the previous sections, the relative transcript levels of the three CA forms in the two plant species in solution cultures grown under different bicarbonate stress treatments were then estimated using real-time quantitative PCR. First, total RNA was isolated from fresh leaf at each treatment in the two plants species. Figure 3 show the relative transcript levels of $O v C A 1$, $O v C A 3$, and $O v C A 4$ in $O$. violaceus leaves, whereas those of $B j C A 1, B j C A 3$, and $B j C A 4$ were in $B$. juncea leaves. These three $C A$ gene transcript levels varied with plant species and bicarbonate stress levels. The levels of $O v C A 1$ and $O v C A 4$ expressions performed a synchronous trend with extended bicarbonate stress, and the highest values were also examined at $5 \mathrm{mM}$ $\mathrm{NaHCO}_{3}$; the levels of $\mathrm{OvCA3}$ were also lower than the control among the $\mathrm{NaHCO}_{3}$-treatments; and the three gene expressions in $O$. violaceus had the lowest values at $10 \mathrm{mM} \mathrm{NaHCO}$ than the control. However, the levels of BjCA1 and BjCA4 expression of B. juncea exhibited a synchronous trend with extent of bicarbonate stress, and the values of expression were gradually dropped with increasing $\mathrm{NaHCO}_{3}$ levels. But $\mathrm{BjCA3}$ expression levels performed a similar trend to those of $O v C A 1$ and $O v C A 4$, with the highest and lowest values of $B j C A 3$ at 5 and $15 \mathrm{mM} \mathrm{NaHCO}$, respectively.

\section{Discussion}

A great many studies have indicated that bicarbonate stress is the major abiotic stress that causes threats via hypertonic stress to plant growth and productivity [1-7]. During bicarbonate stress, water and $\mathrm{CO}_{2}$ supply in some tissues, especially in the photosynthetic tissues, will be even lower than normal conditions due to the hyperosmotic of cytoplasm in plant tissues [12-14]. Therefore, the lower water and $\mathrm{CO}_{2}$ supply to photosynthetic tissues will have a bad affect on the fate of plants. Hence, how to improve and efficient use of water and $\mathrm{CO}_{2}$ inside the plant tissues are crucial to plant survival in bicarbonate stress. Some studies have suggested that some mechanisms participate in the regulation of $\mathrm{CO}_{2}$ and water, including the activity of CA enzyme [21-23], especially in this study. CA is a key enzyme that has been known to regulate various biochemical processes among the plant species under different conditions [20-24]. Furthermore, the crucial role of $\beta$-CAs could participate in the inter-conversion of $\mathrm{HCO}_{3}^{-}$to $\mathrm{CO}_{2}$ and water in higher plants, which can provide partial $\mathrm{CO}_{2}$ and water as photosynthetic substrates for photosynthesis $[25,26]$. The expression of carbonic anhydrase genes in response to $\mathrm{NaHCO}_{3}-$ induced bicarbonate stress has been reported. However, previous studies about the expression of carbonic anhydrase genes and CA activities varied in terms of plant species and the extent of bicarbonate stress $[2,16$, 21, 23-26].

This study revealed that CA activities and gene expression levels of leaves in the two cruciferous plant species performed distinct responses to $\mathrm{NaHCO}_{3}$-induced bicarbonate stress. Furthermore, the phylogenetic relationship studies suggested that three distinct $\beta$-CAs were highly similar to $\beta$-CA gene families (Fig. 2). The bicarbonate stress had 


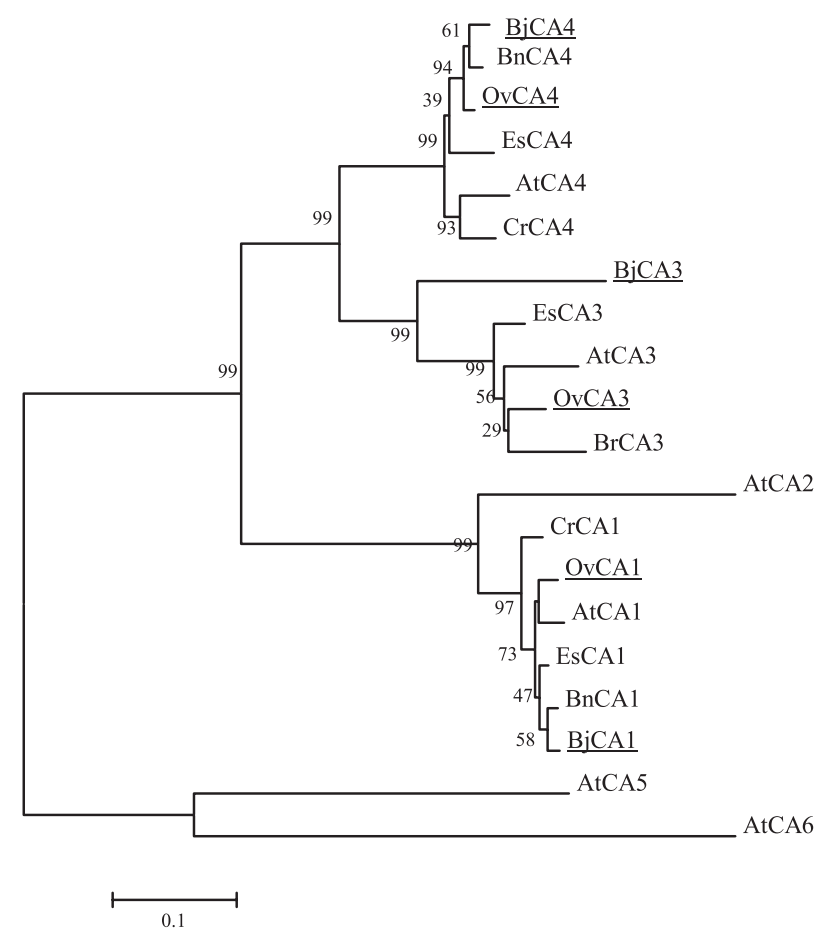

Fig. 2. Phylogenetic relationship of three $O v C A(O v C A 1, O v C A 3$, and $O v C A 4)$ and three $B j C A$ (BjCA1, BjCA3, and $B j C A 4)$ gene sequences to other CAs, respectively. The evolutionary history was inferred using the neighbour-joining method. The phylogenetic tree distances were computed using the Poisson correction method and expressed in the units of the number of sequences. Phylogenetic analyses were conducted in MEGA4. Arabidopsis thaliana (CA1 AT3G01500, CA2 AT5G14740, CA3 AT1G23730, CA4 AT1G70410, CA5 AT4G33580, CA6 AT1G58180); Eutrema salsugineum (CA1 XP006408513, CA3 XP006416059, CA4 XP006390894); Brassica napus (CA1 ADI52861, CA4 CDY57304); Capsella rubella (CA1 XP006298106, CA3 XP006301888); and Brassica rapa (CA3 XP009103160).

significant influence on CA activities between the two plants, which have a significant impact on $B$. juncea larger than $O$. violaceus. CA activities of $O$. violaceus performed significant lower values than the control (except at $5 \mathrm{mM} \mathrm{NaHCO}$ ), whereas that of $B$. juncea exhibited the lower values than the control (expect $15 \mathrm{mM}$ levels). The lowest value of CA activity was at $15 \mathrm{mM} \mathrm{NaHCO}$ levels in $O$. violaceus, but that was at the $10 \mathrm{mM} \mathrm{NaHCO}$ level in B. juncea. These results revealed that $\mathrm{CA}$ may partly participate in regulating the intercellular hyperosmotic effect induced by a high level of bicarbonate anion.

Studies indicated the $\mathrm{CA}$ expressions regulated CA activity [33-34]; and CA expression levels and CA activities varied from plant species, types, and extent of treatments [21-26]. In this study, CA expression of three isoforms in $O$. violaceus and B. juncea were reported to respond to bicarbonate stress induced by $\mathrm{NaHCO}_{3}$, respectively. Furthermore, multiple sequence alignments suggested that the three $\beta$-CAs were identified and
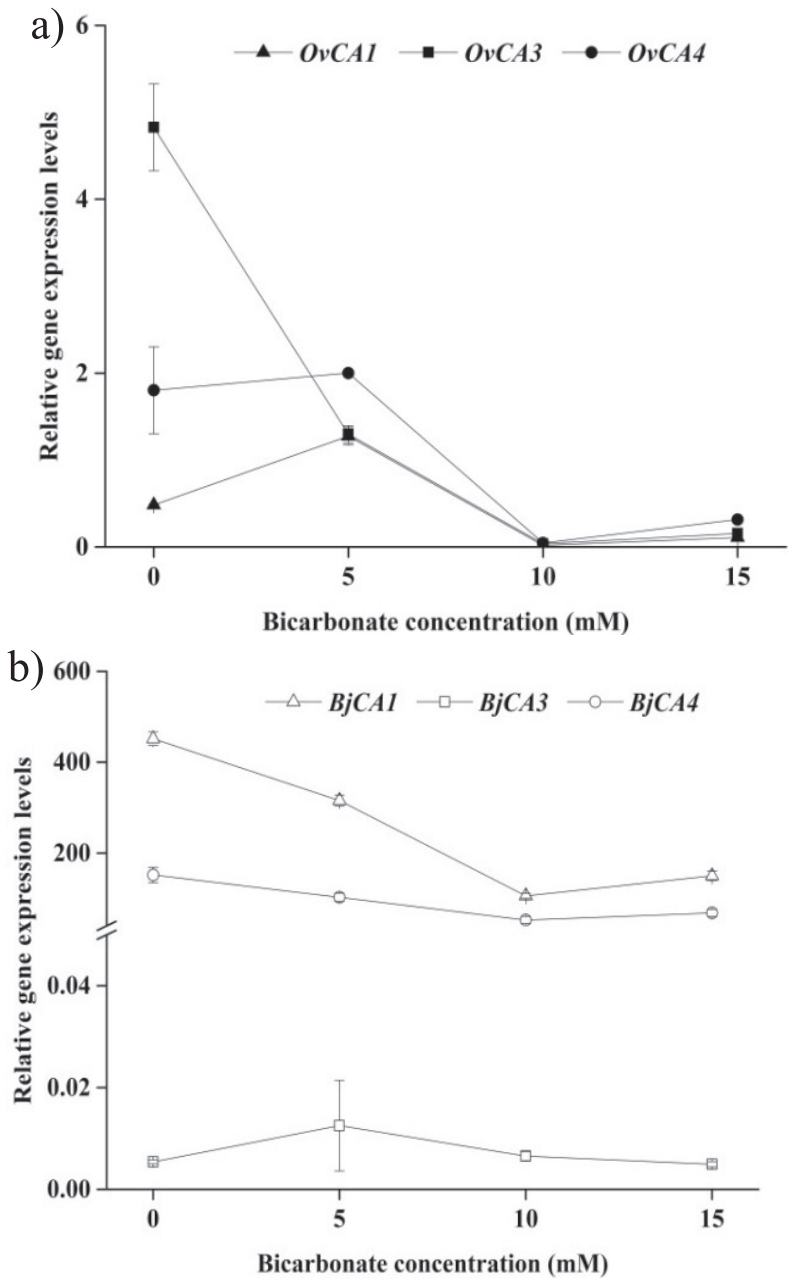

Fig. 3. Relative expression levels of the three carbonic anhydrase genes in Orychophragmus violaceus a) and Brassica juncea b) in response to bicarbonate stress, respectively. Total RNA was isolated from leaves of the two cruciferous plant species subjected to reverse-transcription and followed real-time PCR analysis. Relative transcript levels were calculated relative to the levels of actin gene expression. Values show mean $\pm \operatorname{SE}(n=5)$.

characterized, which were highly similar to chloroplast isoforms CA (OvCA1 and BjCA1), cytoplasm isoforms $\mathrm{CA}(\mathrm{O} \vee C A 3$ and $B j C A 3)$, and plasma membrane isoforms $\mathrm{CA}(\mathrm{OvCA4}$ and $\mathrm{BjCA4})$, respectively. $\mathrm{CA1}$, which was localized at chloroplast and abundant in plant mesophyll cells, has the key function to facilitate $\mathrm{CO}_{2}$ fixation [33]. The decrease in $C A 1$ expression had no significant effect on photosynthetic $\mathrm{CO}_{2}$ fixation. $C A 3$ and $C A 4$, which were localized at the cytoplasm and plasma membranes, function as the inter-conversion of $\mathrm{HCO}_{3}^{-}$to $\mathrm{CO}_{2}$, respectively [24]. Studies had reported increased expression of cytosolic carbonic anhydrase $(C A 3)$ as a result of a significant increase in total CA activity and little impact on $\mathrm{CO}_{2}$ assimilation, but plasma membrane $\mathrm{CA}(\mathrm{CA} 4)$ gene expression only represented a small proportion of total CA activity in plant cells. In this study, the expression of three distinct CA genes and CA activity varied from plant species and extended 

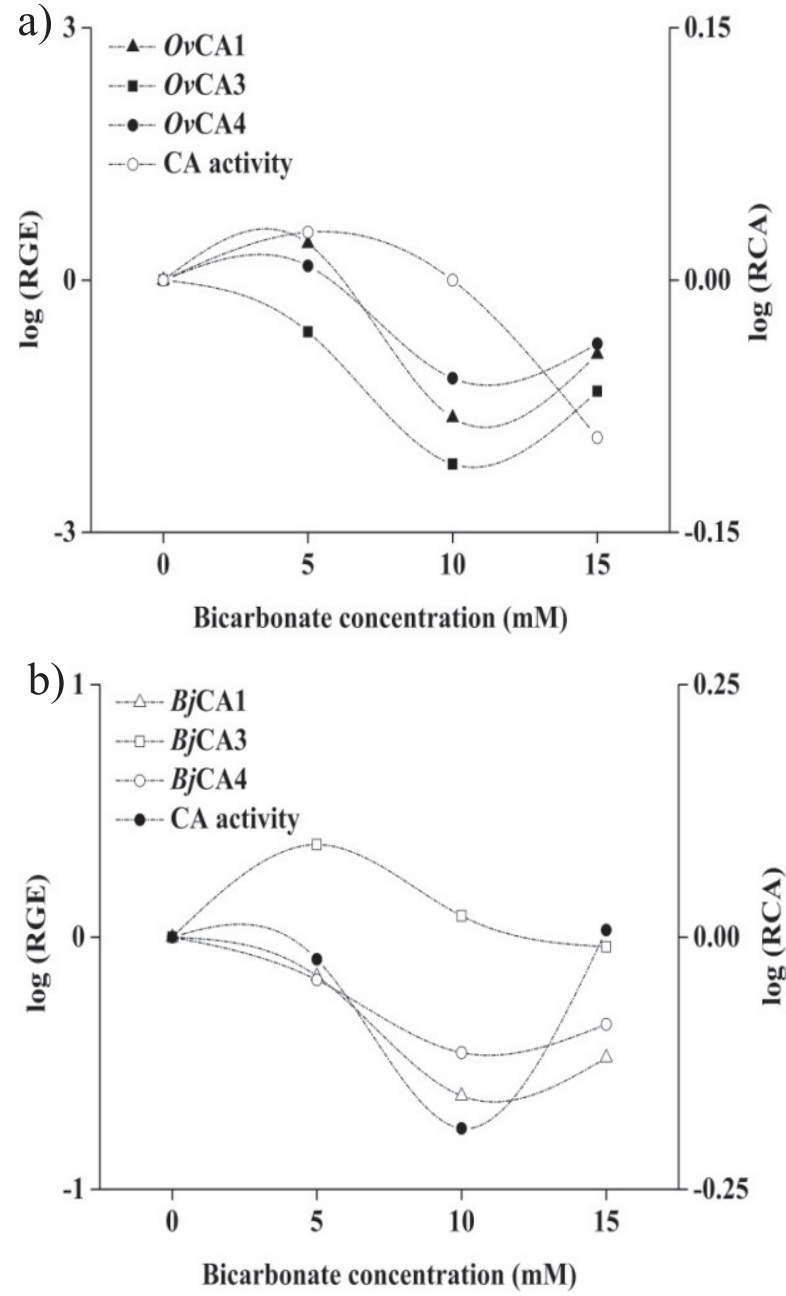

Fig. 4. The log relationship between relative gene expression (RGE) and relative CA activities (RCA, WAU $\mathrm{mg}^{-1}$ Protein) in Orychophragmus violaceus L. a) and Brassica juncea L. b). Values show means on each bicarbonate stress treatment $(n=5)$.

bicarbonate stress. Thus, the presence of three distinct expressions of CA genes in response to $\mathrm{NaHCO}_{3}$ induced bicarbonate stress between $O$. violaceus and $B$. juncea suggested that the two cruciferous plants exhibited different regulating mechanisms under bicarbonate stress.

We also studied the relationship between the expression of three distinct $\beta$-CA genes and the CA activities in response to bicarbonate stress in the two cruciferous plant species (Fig. 4). The expression patterns of the three CA genes during the bicarbonate stress were different between the two plant species. For $O$. violaceus, the expression levels of $O v C A 1$ and OvCA4 in the leaves changed synchronously with CA activities as bicarbonate stress was intensified (Figs 1 and 3a); and the relative gene expression (RGE) levels of $O v C A 1, O v C A 3$, and $O v C A 4$ changed synchronously, but did not change synchronously with relative CA activities (RCA) among bicarbonate-treatments (Fig. 4a). However, in B. juncea, BjCAI and BjCA4 expression levels were significantly higher than that of $B j C A 3$, and dropped synchronously with increasing bicarbonate levels, but BjCAlexhibited the highest value at $5 \mathrm{mM}$ $\mathrm{NaHCO}_{3}$ levels, then dropped among bicarbonate treatments (Fig. 3b). Furthermore, relative CA activities (RCA) changed synchronously with relative $B j C A 1$ and $B j C A 4$ expressions (RGE) of $B$. juncea in responses to bicarbonate stress (Fig. 4b).

With increasing concentrations of bicarbonate stress, the relative expression levels of $O v C A 1$ and $O v C A 4$ changed synchronously with $\mathrm{CA}$ activities in the two plant species. However, the contribution of CA4 to total CA activity was small, and its regulation on the intercellular $\mathrm{HCO}_{3}^{-}$can be ignored; the contribution of CA1 to total CA activity was abundant and relatively stable in abnormal environmental conditions. Therefore, we deduced that the responses of $C A 1$ and $C A 4$ of $O$. violaceus and $C A 3$ of $B$. juncea to bicarbonate stress partly regulate $\mathrm{HCO}_{3}^{-}$into water and $\mathrm{CO}_{2}$ supply to plants, which partly explain that $O$. violaceus could more adapted to $\mathrm{NaHCO}_{3}$-induced bicarbonate stress than B. juncea.

\section{Conclusions}

Our study partially elucidated the differences in gene expression responses and adaptation mechanisms of the two cruciferous plant species exposed to different bicarbonate stress levels. These results suggested that $O$. violaceus exhibited higher $O v C A 3$ expression levels and CA activities than B. juncea. Therefore, $O$. violaceus could better adapt to slight bicarbonate stress than B. juncea. Distinct CA gene expression levels could partly explain these different adaptation strategies of the two cruciferous plants exposed to different bicarbonate stress levels.

\section{Acknowledgements}

This study was supported by the National Key Research and Development Program of China in the $13^{\text {th }}$ Five-year Plan: Ecological industry model and integrated technology and demonstration for the rocky desertification control of the karst plateau gorge (2016YFC0502607 and 2016YFC0502601); the project of Science and Technology of Guizhou Province (Qian Ke He Base [2017]1119); The Growth project of Young Science and Technology Talent of Guizhou Provincial Education Department (Qian Jiao He KY Zi [2016]137); and the Doctor Foundation Project of Guizhou Normal University (2017).

\section{Conflict of Interest}

The authors declare no conflict of interest. 


\section{Abbreviations}

CA: Carbonic anhydrase

qPCR: Quantitative polymerase chain reaction

OvCA: Orychophragmus violaceus CA gene

BjCA: Brassica juncea CA gene

\section{References}

1. YAO K., WU Y.Y. Phosphofructokinase and glucose6-phosphate dehydrogenase in response to drought and bicarbonate stress at transcriptional and functional levels in mulberry. Russian Journal of Plant Physiology, 63 (2), 235, 2016.

2. WU Y.Y., XING D.K. Effect of bicarbonate treatment on photosynthetic assimilation of inorganic carbon in two plant species of Moraceae. Photosynthetica, 50 (4), 587, 2012.

3. ZHANG C., WANG J.L., PU J. B., YAN J. Bicarbonate daily variations in a karst River: the carbon sink effect of subaquatic vegetation photosynthesis. Acta Geologica Sinica-English Edition, 86 (4), 973, 2012.

4. MOHSENIAN Y., ROOSTA H.R., KARIMI H.R., ESMAEILIZADE M. Investigation of the ameliorating effects of eggplant, datura, orange nightshade, local Iranian tobacco, and field tomato as rootstocks on alkali stress in tomato plants. Photosynthetica, 50 (3), 411, 2012.

5. YANG J.Y., ZHENG W., TIAN Y., WU Y., ZHOU D.W. Effects of various mixed salt-alkaline stresses on growth, photosynthesis, and photosynthetic pigment concentrations of Medicago ruthenica seedlings. Photosynthetica, 49 (2), 275, 2011.

6. TAVAKKOLI M.M., ROOSTA H.R., HAMIDPOUR M. Identification of the suitable growth media for alleviating the adverse effect of sodium bicarbonate on gerbera in soilless culture system. Journal of Science \& Technology of Greenhouse Culture, 5 (17), 39, 2014.

7. MOHSENIAN Y., ROOSTA H.R. Effects of Grafting on Alkali Stress in Tomato Plants: Datura Rootstock Improve Alkalinity Tolerance of Tomato Plants. Journal of Plant Nutrition, 38 (1), 51, 2015.

8. BABUIN M.F., CAMPESTRE M.P., ROCCO R., BORDENAVE C.D., ESCARAY F.J., ANTONELLI C., CALZADILlA P., GÁRRIZ A., SERNA E., CARRASCO P., RUIZ O.A., MENENDEZ A.B. Response to long-term $\mathrm{NaHCO}_{3}$-derived alkalinity in model Lotus japonicus Ecotypes Gifu B-129 and Miyakojima MG-20: transcriptomic profiling and physiological characterization. Plos One, 9 (5), 97, 2014.

9. KOBAYASHI S., SATONE H., TAN E., KUROKOCHI H., ASAKAWA S., LIU S., TAKANO T. Transcriptional responses of a bicarbonate-tolerant monocot, Puccinellia tenuiflora, and a related bicarbonate-sensitive species, Poa annua, to $\mathrm{NaHCO}_{3}$ stress. International Journal of Molecular Sciences, 16 (1), 496, 2014.

10. PANG Q., ZHANG A., ZANG W., WEI L., YAN X. Integrated proteomics and metabolomics for dissecting the mechanism of global responses to salt and alkali stress in Suaeda corniculata. Plant \& Soil, 402 (1-2), 379, 2016.

11. ABBASI G.H., AKHTAR J., AHMAD R., JAMIL M., ANWAR-UL-HAQ M., ALI S., IJAZ M. Potassium application mitigates salt stress differentially at different growth stages in tolerant and sensitive maize hybrids. Plant Growth Regulation, 76 (1), 111, 2015.
12. WANG R., WU Y.Y., XING D.K., HANG H.T., XIE T.X., YANG X.Q., ZHANG K.Y., RAO S. Biomass production of three biofuel energy plants' use of a new carbon resource by carbonic anhydrase in simulated karst soils: mechanism and capacity. Energies, 10 (9), 1370, 2017.

13. WANG R., WU Y.Y., HANG H.T., LIU Y., XIE T.X., ZHANG K., LI H.T. Orychophragmus violaceus, L. a marginal land-based plant for biodiesel feedstock: Heterogeneous catalysis, fuel properties, and potential. Energy Conversion \& Management, 84 (June), 497, 2014.

14. WANG R., WU Y.Y., XING D.K., HANG H.T., LIU Y., ZHANG K.Y., YAO K. Physiological characteristics and inorganic carbon-usage capacity of three biomass plants under simulative karst adversity(Bicarbonate Stress). Earth \& Environment, 43 (1), 21, 2015 [In Chinese].

15. AZEEM A., WU Y.Y., XING D.K., JAVED Q., UIIAH I. Photosynthetic response of two okra cultivars under salt stress and re-watering. Journal of Plant Interactions, 12 (1), 67, 2017.

16. MÜLLER W.E., QIANG L., SCHRÖDER H.C., HÖNIG N., YUAN D., GREBENJUK V.A., MUSSINO F., GIOVINE M., WANG X. Carbonic anhydrase: a key regulatory and detoxifying enzyme for Karst plants. Planta, 239 (1), 213, 2014.

17. HANG H.T., WU Y.Y. Quantification of photosynthetic inorganic carbon utilisation via a bidirectional stable carbon isotope tracer. Acta Geochimica, 35 (2), 130, 2016.

18. WU Y.Y., WU X.M., LI P.P., ZHAO Y.G., LI X.T., ZHAO X.Z. Comparison of photosynthetic activity of Orychophragmus violaceus, and oil-seed rape. Photosynthetica, 43 (2), 299, 2005.

19. HAYAT S., ALI B., HASAN S.A., AHMAD A. Brassinosteroid enhanced the level of antioxidants under cadmium stress in Brassica juncea. Environmental Experimental Botany, 60 (1), 33, 2007.

20. LINDSKOG S. Structure and mechanism of carbonic anhydrase. Pharmacology \& Therapeutics, 74 (1), 1, 1997.

21. SUN W.H., WU Y.Y., SUN Z.Z., WU Q.X., WEN X.Y. Enzymatic characteristics of higher plant carbonic anhydrase and its role in photosynthesis. Journal of Plant Studies, 3 (2), 39, 2014.

22. BADGER M. The roles of carbonic anhydrases in photosynthetic $\mathrm{CO}_{2}$ concentrating mechanisms. Photosynthesis Research, 77 (2-3), 83, 2003.

23. HU H., BOISSONDERNIER A., ISRAELSSONNORDSTROM M., BOHMER M., XUE S., RIES A., GODOSKI J., KUHN J.M., SCHROEDER J.I. Carbonic anhydrases are upstream regulators of $\mathrm{CO}_{2}$-controlled stomatal movements in guard cells. Nature Cell Biology, 12 (1), 87, 2010.

24. TETU S.G., TANZ S.K., VELLA N., BURNELL J.N., LUDWIG M. The Flaveria bidentis $\beta$-carbonic anhydrase gene family encodes cytosolic and chloroplastic isoforms demonstrating distinct organ-specific expression patterns. Plant Physiology, 144 (3), 1316, 2007.

25. FABRE N., REITER I.M., BECUWELINKA N., GENTY B., RUMEAU D. Characterization and expression analysis of genes encoding $\alpha$ and $\beta$ carbonic anhydrases in Arabidopsis. Plant Cell \& Environment, 30 (5), 617, 2007.

26. WANG M., ZHANG Q., LIU F.C., XIE W.F., WANG G.D., WANG J., GAO Q.H., DUAN K. Family-wide expression characterization of Arabidopsis beta-carbonic anhydrase genes using qRT-PCR and promoter: GUS fusions. Biochimie, 97 (1), 219, 2014.

27. LI H., CHENG Z. Hoagland nutrient solution promotes the growth of cucumber seedlings under light-emitting 
diode light. Acta Agriculturae Scandinavica, 65 (1), 74, 2015.

28. WU Y.Y., SHI Q.Q., WANG K., LI P.P., XING D.K., ZHU Y.L., SONG Y.J. An electrochemical approach coupled with $\mathrm{Sb}$ microelectrode to determine the activities of carbonic anhydrase in the plant leaves. Future Intelligent Information Systems. 87; Springer, 2011.

29. AMINIAN M., NABATCHIAN F., VAISI-RAYGANI A., TORABI M. Mechanism of Coomassie Brilliant Blue G-250 binding to cetyl-trimethyl-ammonium bromide: an interference with the Bradford assay. Analytical Biochemistry, 434 (2), 287, 2013.

30. WU X., WAN X.F., WU G., XU D., LIN G. Phylogenetic analysis using complete signature information of whole genomes and clustered Neighbour-Joining method. International Journal of Bioinformatics Research \& Applications, 2 (3), 219, 2006.

31. CHRISTOU A., GEORGIADOU E.C., FILIPPOU P., MANGANARIS G.A., FOTOPOULOS V. Establishment of a rapid, inexpensive protocol for extraction of high quality rna from small amounts of strawberry plant tissues and other recalcitrant fruit crops. Gene, 537 (1), 169, 2014.

32. MALASH G.F., EL-KHAIARY M.I. Piecewise linear regression: A statistical method for the analysis of experimental adsorption data by the intraparticlediffusion models. Chemical Engineering Journal, 163 (3), 256, 2010.

33. BURÉN S., ORTEGAVILLASANTE C., BLANCORIVERO A., MARTINEZBERNARDINI A., SHUTOVA T., SHEVELA D., MESSINGER J., BAKO L., VILLAREJO A., SAMUELSSON G. Importance of post-translational modifications for functionality of a chloroplast-localized carbonic anhydrase (CAH1) in Arabidopsis thaliana. Plos One, 6( 6), e21021, 2011.

34. HU H., RAPPEL W.J., OCCHIPINTI R., RIES A., BÖHMER M., YOU L., XIAO C., ENGINEER C.B., BORON W.F., SCHROEDER J.I. Distinct cellular locations of carbonic anhydrases mediate carbon dioxide control of stomatal movements. Plant Physiology, 169 (2), 1168, 2015. 
